\title{
Myelolipoma: an unusual differential of duodenal polyp
}

\author{
Arkadeep Dhali 지, ${ }^{1}$ Sukanta Ray, ${ }^{1}$ Dijendra Nath Biswas 지, ${ }^{2}$ Gopal Krishna Dhali ${ }^{3}$
}

'Department of GI Surgery, IPGME and R, Kolkata, West Bengal, India

${ }^{2}$ Department of Radiology, IPGME and R, Kolkata, West Bengal, India

${ }^{3}$ Department of

Gastroenterology, IPGME and R, Kolkata, West Bengal, India

\section{Correspondence to} Dr Arkadeep Dhali; arkadipdhali@gmail.com

Accepted 21 November 2021

Check for updates

(C) BMJ Publishing Group Limited 2021. No commercial re-use. See rights and permissions. Published by BMJ.

To cite: Dhali A, Ray $S$ Biswas DN, et al. BMJ Case Rep 2021;14:e246444 doi:10.1136/bcr-2021246444

\section{DESCRIPTION}

Polypoidal lesions of the duodenum comprises close differentials like a gastrointestinal stromal tumour, Brunner's gland hamartoma, adenocarcinoma, lymphoid, carcinoid, neuroendocrine tumour and other neuroblastic tumours. ${ }^{1}$ Myelolipoma on the other hand predominantly arises from the adrenal gland. Although few cases of extra-adrenal myelolipomas are reported, they were found to originate from the presacral region, liver, gastric antrum, mediastinum, pleura and retroperitoneum, with the most common extra-adrenal site being the presacral area. $^{2}$ To the best of our knowledge, there are no cases reported in the existing medical literature on myelolipoma arising from the duodenum and this is the first case reported.

We report a 40-year-old woman, who presented to our outpatient clinic with a history of haematemesis for 5 days and melena for 8 days. She also complained of mild abdominal discomfort, loss of appetite and weight loss since the last 4 months. Pallor was present and rest of the physical examination was unremarkable. Her haemoglobin was $6.5 \mathrm{gm} / \mathrm{dL}$ and was treated with three units of blood transfusion. Posttransfusion haemoglobin was $12 \mathrm{gm} / \mathrm{dL}$. Upper gastrointestinal (UGI) endoscopy was performed, which revealed a sessile polypoidal swelling with a smooth surface and a large base in the first part of the duodenum measuring $>2 \mathrm{~cm}$ in the posterior wall of the duodenal bulb (figure 1A). There was no visible ulcer or bleeding from the lesion at the time of evaluation. To characterise the lesion better and to know the layer of origin, endoscopic ultrasound (EUS) was performed (figure 1B), which revealed a $2.4 \mathrm{~cm}$ hyperechoic, submucosal lesion with no calcification, cystic change or ductal structure. An EUS-guided fine-needle aspiration (FNA) was done, which was inconclusive. Contrastenhanced CT was performed to look for any exophytic component of the lesion, which showed a heterogeneously enhancing polypoidal mass arising from the posterior wall of the duodenal bulb measuring $2.4 \times 2 \times 2 \mathrm{~cm}$ with no periduodenal fat stranding (figure 1C). Endoscopic polypectomy was attempted but failed due to the broad base of the lesion and compromised luminal size, and hence surgical intervention was warranted. She underwent open polypectomy with pyloroplasty. Intraoperatively after partial kocherisation, the duodenal cap was opened longitudinally, and a sessile polyp measuring approximately $2.5 \times 2 \mathrm{~cm}$ was removed after transfixing its base. The mucosal gap was repaired. The longitudinal incision was extended towards the pyloric antrum and closed transversely.

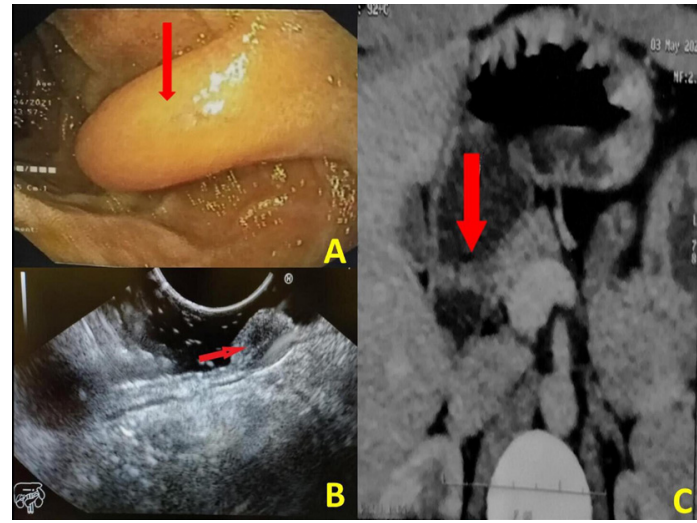

Figure 1 Preoperative evaluation: (A) esophagogastroduodenoscopy image showing a smooth sessile polypoidal swelling with a large base in the first part of the duodenum in the posterior wall of the duodenal bulb with no ulcer or bleeding, (B) endoscopic ultrasound (EUS) showing a $2.4 \mathrm{~cm}$ hyperechoic lesion arising from the second layer (submucosa) with no calcification, cystic change or ductal structure and (C) contrast-enhanced CT showing a heterogeneously enhancing polypoidal mass arising from the posterior wall of duodenal bulb measuring $2.4 \times 2 \times 2 \mathrm{~cm}$ with no periduodenal fat stranding.

Operative time was $125 \mathrm{~min}$ and operative blood loss was $200 \mathrm{~mL}$. The resected specimen was sent for histopathological examination, which showed an admixture of mature adipose tissue interspersed with trilineage haematopoietic cells. Individual

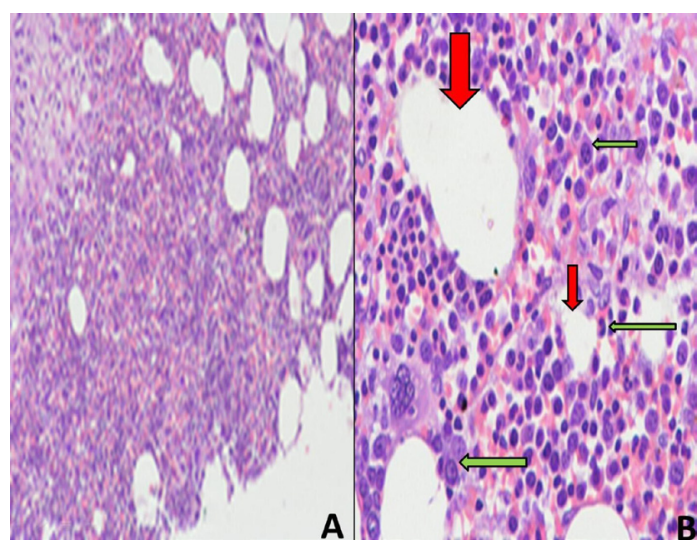

Figure 2 H\&E image (A:40x, B:100x) showing admixture of mature adipose tissue (red arrow) interspersed with trilineage haematopoietic cells (green arrow). Individual adipocytes were large, round with eccentrically placed small nucleus and abundant clear cytoplasm, suggestive of myelolipoma. 
adipocytes were large, round with eccentrically placed small nuclei and abundant clear cytoplasm. Overall, it was suggestive of myelolipoma (figure $2 \mathrm{~A}, \mathrm{~B}$ ). The postoperative period was uneventful, and she was doing well on an 18-month follow-up.

Polypoidal lesions of the duodenum are known to cause UGI haemorrhage and present as described above. The histopathological diagnosis of myelolipoma from an unusual location was unique in this case. Extra-adrenal myelolipoma comprises 14\% of all myelolipomas. Proposed theories for its etiopathogenesis are embolisation of haematopoietic components from bone marrow tissue, or reactivation of embryonic peritoneal connective tissue in response to a triggered stimulus, like an endocrine dysfunction or a septic condition. ${ }^{3}$ Generally, these tumours are asymptomatic and do not require any intervention, but may turn symptomatic if it is large enough to cause mass effect or bleeding-induced complications. In most cases, they are picked up incidentally by radiological investigations. A typical contrast-enhanced CT describes it as a heterogenous (admixture of fat tissue and other soft tissue), well-circumscribed hypodense lesion $(<10 \mathrm{HU})$. With these radiological features, differentials are myelolipoma, lipoma, liposarcoma, teratoma and even extramedullary haematopoiesis. ${ }^{3}$ Due to their benign nature, asymptomatic tumours and lesions $<6 \mathrm{~cm}$ do not require any form of intervention and an annual imaging survillance is advised. ${ }^{2}$ In our case, not only was it symptomatic, but also we did not even had a preoperative diagnosis. This may be attributed to the small size of the tumour which did not fit into the typical radiological description. Moreover, the UGI endoscopic findings of a polypoidal lesion with smooth overlying mucosa were pointing more towards common pathological entities like Brunner's gland hamartoma or gastrointestinal stromal tumour. The EUS-guided FNA sampling was

\section{Learning points}

- Myelolipoma even though extremely rare can be a differential diagnosis for polypoidal lesions of duodenum.

- Endoscopic biopsy may miss the diagnosis due to submucosal location of the lesion.

- Asymptomatic cases do not warrant treatment, although yearly follow-up is advised. also inadequate in our case. Hence we managed it as a benign duodenal polyp and it was adequate. Our own unit does not have experience in advanced EUS techniques or advanced laparoscopic techniques, and hence we chose to remove the polyp at an open procedure. But, other centres might have approached the excision in other ways.

Histopathological evaluation stays the gold standard investigation, where mature adipose tissue interspersed with haematopoietic cells are seen. ${ }^{4}$

Hence, clinicians should be aware of this rare pathological entity which can mimic other common differentials of polypoidal lesions of duodenum. Moreover, biopsy and histological examination is essential for diagnosis to differentiate myelolipomas from other benign and malignant lesions as the treatment and outcome change accordingly.

Contributors AD: Conception, design of the study, acquisition of the data, drafting the manuscript and final approval of the version to be submitted. SR: Conception, design of the study, acquisition of the data, drafting the manuscript and final approval of the version to be submitted. DNB: Acquisition of the data, final approval of the version to be submitted. GKD: Acquisition of the data, final approval of the version to be submitted.

Funding The authors have not declared a specific grant for this research from any funding agency in the public, commercial or not-for-profit sectors.

Competing interests None declared.

Patient consent for publication Consent obtained directly from patient(s). Provenance and peer review Not commissioned; externally peer reviewed.

Case reports provide a valuable learning resource for the scientific community and can indicate areas of interest for future research. They should not be used in isolation to guide treatment choices or public health policy.

\section{ORCID iDs}

Arkadeep Dhali http://orcid.org/0000-0002-1794-2569

Dijendra Nath Biswas http://orcid.org/0000-0002-0097-3991

\section{REFERENCES}

1 Ma MX, Bourke MJ. Management of duodenal polyps. Best Pract Res Clin Gastroenterol 2017;31:389-99.

2 Huang Q, Parmer C, Muniraj T, et al. Fine needle aspiration cytology of peripancreatic myelolipoma. Diagn Cytopathol 2020;48:491-3.

3 Yelikar BR, Mamatha K, Chawla A, et al. Extra-Adrenal myelolipoma: tumour at unusual site. JCDR 2017;11.

4 Chen KT, Felix EL, Flam MS. Extraadrenal myelolipoma. Am J Clin Pathol 1982;78:386-9.

Copyright 2021 BMJ Publishing Group. All rights reserved. For permission to reuse any of this content visit

https://www.bmj.com/company/products-services/rights-and-licensing/permissions/

BMJ Case Report Fellows may re-use this article for personal use and teaching without any further permission.

Become a Fellow of BMJ Case Reports today and you can:

- Submit as many cases as you like

- Enjoy fast sympathetic peer review and rapid publication of accepted articles

- Access all the published articles

Re-use any of the published material for personal use and teaching without further permission

Customer Service

If you have any further queries about your subscription, please contact our customer services team on +44 (0) 2071111105 or via email at support@bmj.com.

Visit casereports.bmj.com for more articles like this and to become a Fellow 